Social Sciences, Humanities and Education Journal (SHE Journal)

Volume 1 (3) 46 - 52, September 2020 | ISSN: 2720-9946 (Online) | ISSN: 2723-3626 (Print)

The article is published with Open Access at: http://e-journal.unipma.ac.id/index.php/SHE

\title{
CLASSROOM: VIDEO FOR HOMEWORK
}

Parveen Sarjit Sidhu $\bowtie$, General Studies Department, Polytechnic Balik Pulau, Malaysia

\begin{abstract}
This action research was conducted in order to investigate the students experience and perception towards using the video making assessment approach when presenting their oral communication assessment. This was to see the impact on the students compared to presenting the traditional way in -class. Forty-five (45) respondents undertaking DUE 3012 - Communicative English 2 in Polytechnic Balik Pulau, Information T echnology Department, participated in this study. The respondents had to make a video based on Chapter 1 - Product and Services whereby it will be evaluated as their oral presentation assessment. A Likert Scale questionnaire was distributed and the data were tabulated using descriptive statistics. The outcome of the study was that the respondents had a positive perception towards this approach and it hel ped them to build their confidence level to use the English Language. Besides that, the respondents felt that this approach of assessment was successful and benefic ial in helping them to understand the chapter better.
\end{abstract}

Keywords: video making, oral communication assessment, english language, confidence level.

凶parveen@pbu.edu.my

Citation: Sidhu, P. S. (2020). Classroom: video for homework . Social Sciences, Humanities and Education Journal (SHE Journal), 1(3), 46 - 52. DOI: 10.25273/she.v1i3.7552

\section{$(c c)$ EY-NC-SA}

Published by Universitas PGRI Madiun. This work is licensed under the Creative Commons Attribution NonCommercialShareAlike 4.0 International License. 


\section{INTRODUCTION}

Polytechnics in Malaysia mainly produce skilled workers that are demanded by the industries to fulfil the needs for the country's development. These skilled workers that are 'fresh graduates' not only are required to have certain skills but also able to communicate in the English language. Hence, the polytechnics are strictly required to produce graduates that are well verse in the English language, mainly the graduates must be confident in speaking the language. This is to ensure that the graduates can converse with their superiors, co-workers and clients, so that information will be delivered-received correctly and no misunderstanding occurs.

To achieve this goal, the English language syllabus implemented in Malaysian polytechnics was designed as such that majority of the assessments are based on oral communication- oral presentation and role-play to provide a platform for the students to practice and apply their oral communication skills in the classroom. As second-language learners (L2), the students have limited space to converse using the English language as they retain the use of their mother tongue as the communication medium most of the time. Apart from that, they vary from their proficiency and competence level in the English language. Thus, this platform is to train and prepare the students to enter the real life-working environment. Referring to the Malaysia Education Blueprint 20132025 (p.104), it has clearly stated,

"In line with the National Education Philosophy, the Ministry's approach to education is focused on developing students holistically. This means, the education system addresses intellectual, spiritual, emotional, and physical development."

\section{Teaching Oral Communication}

Teaching oral communication in English language has been a challenge especially in a classroom where English is a second language (ESL). As Brown (2000, p.267) mentioned, the method used in teaching oral communication varies when the students, teacher and the classroom environment changes. This has proven to be the major obstacle faced by the students as learners and the teachers as educators. Being in a system, Malaysian education, which does not implement streaming process, has created a tense environment for the teachers and the learners, as 'one size does not fit all'.

Even though the students are exposed to the speaking element since year 1 , but till to date they still cannot present well in front of the classroom as they experience ample of obstacles - poor vocabulary, pronunciation problem, repetition of points and lapsing into their first language (L1). During presentation, students' mind is overshadowed by their self-consciousness to impress their teacher as they are playing the role of an observer (Brown, H.D., 2000, p.269).

Students always encounter stage fright when asked to present in front of the classroom. This results in the students reading from notes, no eye contact or any sorts of body gestures and be likely to ignore the teacher and classmates. The students panic when they make mistakes as they are being assessed and there is no way they could rewind time to correct their mistakes and this will automatically bring down their confident level when they are in the action of presenting and followed by their failure in their oral presentation and role-play assessment.

\section{Video Making}

According to Harmer (2004, p.282), video is a recognized medium that has been widely used in the educational system, in the teaching and learning process, as video provides an added value to the learning experience: (a) seeing language in use, (b) crosscultural awareness, (c) the power of creation, and (d) motivation. Furthermore, every student learns 
differently and has their own specific learning style. According to Zhu (2012), "Video appeals to different senses via 'sound, image, colour and shape' at the same time" (as cited in Ilin, Kutlu \& Kutluay, 2012, p.273). Hence, when videos are used, all the students can benefit and learn even though they differ in various aspects.

Throughout the writer's observation as long as eight years, majority of the students in a classroom gets engrossed when a video is playedmovies, short clips or advertisements. Thus, this triggered the writer, that students should produce their own video (video making) specifically for their assessments that involves oral presentations and role-play. When given the access to a camera, making and acting in an own video clip as main actors (Brown, 2000) would give confidence and encourage the students to speak the English language.

By implementing video making in students' assessments, it spontaneously teaches the students to plan, organize, write, communicate, collaborate and execute. This media has made a tremendous change in the education system, from chalk and talk to creating own educational videos where lecturers upload in various online learning platforms. Hence, in this digital technology era, students should be exposed to video making as they might be required to create their own videos to be used in presentations as nowadays everything is done via online- distance learning and Massive Open Online Course (MOOC).

Ng Choo Ting (2013) conducted a pilot research on students' perception towards the usage of video projects in the English language classroom. Thirtyfive (35) foundation students of intermediate level in the English language gave positive feedback. The video project gave them excitement in creating a video, as they were able to use their creativity and this led to the improvement in their self-confidence whereby they were willing to communicate in English. Apart from that, the students could relate their video to the real life situation.

In another study by Greene \& Crespi (2012) that researched on the value of student created videos in classroom, had resulted to a positive outcome. The respondents found that the experience of making videos was engaging and related to their studies accounting and marketing course. This method has helped them in reinforcing concepts that they have learned in the classroom.

Hulsizer (2016) conducted a study about students' opinion on studentproduced videos to be used for exam review in Mathematics course at a small liberal art college for men. Results showed that the students relished the video project and was beneficial to them as they viewed it outside the classroom period. The students also mentioned that by creating the videos, it helped them learn the subject better.

Thus, this transformation was needed to help the students to build their confident level and improve their English language that is in line with Malaysia Education Blueprint 2013-2025; teachers have to make a drastic change in their teaching approaches to cater to the students learning style to enable them to perform well, all-rounded. For that reason, this action research will be focusing on an alternative approach to in-class video making presentation for assessments. This video making presentations can be an effective and efficient way for students to build their confidence in speaking the English language in an engaging, creative and enjoyable way.

\section{RESEARCH METHODOLOGY}

Based on the problem investigated, thus, two research questions were formulated. The research questions are as follows:

1. What are the differences the students experience in the video making 
presentation versus in-class presentation?

2. What are the students' perceptions towards using video making assessment approach in their oral communication presentation?

This action research used a quantitative method, questionnaires which were distributed to 45 respondents after the completion of video making and video presentation session. The respondents were officially from Polytechnic Balik Pulau, Pulau Pinang undertaking the subject DUE 3012- Communicative English 2. They consists of three classes: two classes taught by the writer herself and one class by another lecturer. They were all from Semester 3 and mix ability students.

The duration of the action research took around 8 weeks taking into account the teaching of Chapter 1 and the process of video making until video presentation. The video was based on Chapter 1Product \& Services. Respondents were to create a product related to their major course (networking or programming) and to make a video that contains the description of their product in groups of three or four. The video was based on the video making requirement that was fixed for this oral presentation assessment.

The questionnaire consists of 15 questions in the form of Likert scale strongly disagree (1), disagree (2), neutral (3), agree (4) and strongly agree (5). Questions were divided into three categories: (a) Respondents' Evaluation on the 'Video Making' Assessment, (b) Respondents' Evaluation on 'Video Making' Process Versus Traditional Approach, and (c) Respondents' Perception on 'Video Making'. The data were than tabulated and analysed quantitatively by using descriptive statistics, frequency and percentages.

\section{FINDINGS AND DISCUSSIONS}

This action research discovered that the implementation of video making for oral presentation assessment replacing the traditional approach in- class, had significantly given a positive impact on the students' perception and attitude towards video making.

The results presented in Table 1, 2, and 3 indicate that the overall percentage of the students had positive perception and experience in using video making approach to present their oral presentation assessment.

Table 1 shows the respondents opinion in using the 'Video Making' approach to replace the traditional way in presenting their oral presentation assessment. The findings revealed that $84.44 \%$ of the respondents strongly agreed and $13.33 \%$ agreed that this approach of assessment incorporates ICT in their P\&P. Meanwhile, 1 respondent $(2.22 \%)$ was uncertain. It was also found that $91.11 \%$ strongly agreed and $8.89 \%$ agreed that 'Video Making' is interesting and challenging. The time allocated to the students to complete the assessment using this approach was suitable as all the respondents (100\%) agreed to this statement. Thus, it can be concluded that this method does not give any frustration or hinder the students to complete the video.

Referring to Table 2, $100 \%$ of
the polytechnic respondents mentioned that they experienced an increase in their knowledge and understanding on Chapter 1 using the 'Video Making' approach as compared to presenting in-class. As for being more confident to speak the English language and feeling less stress as the respondents enjoy making the video, only $1(2.22 \%)$ respondent was unsure and the rest, $88.89 \%$ strongly agreed and $8.89 \%$ agreed respectively. Majority of the respondents (97.78\%) agreed that the 'Video Making' approach is successful and beneficial to the respondents. Therefore it can be inferred that the "Video Making' approach has indeed brought positive changes in the English classroom. 
TABLE 1. Respondents' Evaluation on the 'Video Making' Assessment

\begin{tabular}{|c|c|c|c|c|c|c|c|c|c|c|}
\hline \multirow[t]{2}{*}{ Questions } & \multicolumn{2}{|c|}{$\begin{array}{l}\text { Strongly } \\
\text { Disagree }\end{array}$} & \multicolumn{2}{|c|}{ Disagree } & \multicolumn{2}{|c|}{ Neutral } & \multicolumn{2}{|c|}{ Agree } & \multicolumn{2}{|c|}{ Strongly Agree } \\
\hline & $f(x)$ & $\%$ & $f(x)$ & $\%$ & $f(x)$ & $\%$ & $f(x)$ & $\%$ & $f(x)$ & $\%$ \\
\hline $\begin{array}{l}\text { 1. Incorporates } \\
\text { ICT in P\&P. }\end{array}$ & - & - & - & - & 1 & 2.22 & 6 & 13.33 & 38 & 84.44 \\
\hline $\begin{array}{l}\text { 2. Interesting and } \\
\text { challenging for } \\
\text { students. }\end{array}$ & - & - & - & - & - & - & 4 & 8.89 & 41 & 91.11 \\
\hline $\begin{array}{l}\text { 3. Allocation of } \\
\text { time to complete } \\
\text { the assessment is } \\
\text { suitable. }\end{array}$ & - & - & - & - & - & - & 6 & 13.33 & 39 & 86.67 \\
\hline
\end{tabular}

TABLE 2. Respondents' Evaluation on 'Video Making' Process Versus Traditional Approach

\begin{tabular}{|c|c|c|c|c|c|c|c|c|c|c|}
\hline \multirow[t]{2}{*}{ Questions } & \multicolumn{2}{|c|}{$\begin{array}{l}\text { Strongly } \\
\text { Disagree }\end{array}$} & \multicolumn{2}{|c|}{ Disagree } & \multicolumn{2}{|c|}{ Neutral } & \multicolumn{2}{|c|}{ Agree } & \multicolumn{2}{|c|}{ Strongly Agree } \\
\hline & $f(x)$ & $\%$ & $f(x)$ & $\%$ & $f(x)$ & $\%$ & $f(x)$ & $\%$ & $f(x)$ & $\%$ \\
\hline $\begin{array}{l}\text { 4. An increase in } \\
\text { knowledge/ } \\
\text { understanding as } \\
\text { compared to } \\
\text { presenting in } \\
\text { classroom. }\end{array}$ & - & - & - & - & - & - & 5 & 11.11 & 40 & 88.89 \\
\hline $\begin{array}{l}\text { 5. More confident } \\
\text { to speak English } \\
\text { when using video. }\end{array}$ & - & - & - & - & 1 & 2.22 & 4 & 8.89 & 40 & 88.89 \\
\hline $\begin{array}{l}\text { 6. Less stress and } \\
\text { enjoy doing the } \\
\text { video compare to } \\
\text { classroom } \\
\text { presentation. }\end{array}$ & - & - & - & - & 1 & 2.22 & 4 & 8.89 & 40 & 88.89 \\
\hline $\begin{array}{l}\text { 7. In general, the } \\
\text { Innovation is } \\
\text { successful and } \\
\text { beneficial }\end{array}$ & - & - & - & - & 1 & 2.22 & 3 & 6.67 & 41 & 91.11 \\
\hline
\end{tabular}


TABLE 3. Respondents' Perception on 'Video Making'

\begin{tabular}{|c|c|c|c|c|c|c|c|c|c|c|}
\hline \multirow[t]{2}{*}{ Questions } & \multicolumn{2}{|c|}{$\begin{array}{l}\text { Strongly } \\
\text { Disagree }\end{array}$} & \multicolumn{2}{|c|}{ Disagree } & \multicolumn{2}{|c|}{ Neutral } & \multicolumn{2}{|c|}{ Agree } & \multicolumn{2}{|c|}{ Strongly Agree } \\
\hline & $f(x)$ & $\%$ & $f(x)$ & $\%$ & $f(x)$ & $\%$ & $f(x)$ & $\%$ & $f(x)$ & $\%$ \\
\hline $\begin{array}{l}\text { 8. I know the } \\
\text { objectives of } \\
\text { Chapter } 1 \text {. }\end{array}$ & - & - & - & - & - & - & 6 & 13.33 & 39 & 86.67 \\
\hline $\begin{array}{l}\text { 9. I enjoy creating } \\
\text { the video. }\end{array}$ & - & - & - & - & 1 & 2.22 & 2 & 4.44 & 42 & 93.33 \\
\hline $\begin{array}{l}10 . \text { I could see my } \\
\text { weakness and } \\
\text { strengths. }\end{array}$ & - & - & - & - & - & - & 4 & 8.89 & 41 & 91.11 \\
\hline $\begin{array}{l}11 . \text { I could correct } \\
\text { myself by } \\
\text { rerecording. }\end{array}$ & - & - & - & - & 1 & 2.22 & 4 & 8.89 & 40 & 88.89 \\
\hline $\begin{array}{l}\text { 12. I started to like } \\
\text { learning English. }\end{array}$ & - & - & - & - & 1 & 2.22 & 3 & 6.67 & 41 & 91.11 \\
\hline $\begin{array}{l}\text { 13. I could spend } \\
\text { more time } \\
\text { discussing with } \\
\text { my lecturer. }\end{array}$ & - & - & - & - & - & - & 4 & 8.89 & 41 & 91.11 \\
\hline $\begin{array}{l}\text { 14. I like recording } \\
\text { outdoor. }\end{array}$ & - & - & 1 & $\begin{array}{c}2.2 \\
2\end{array}$ & - & - & 3 & 6.67 & 41 & 91.11 \\
\hline $\begin{array}{l}\text { 15.I like watching } \\
\text { my video }\end{array}$ & - & - & 1 & $\begin{array}{c}2.2 \\
2\end{array}$ & - & - & 3 & 6.67 & 41 & 91.11 \\
\hline
\end{tabular}

Table 3 explains about the respondents' perspective on the video making approach. 45 respondents (100\%) totally agreed that by using this approach, they know the learning objectives of Chapter 1 - Product \& Services. The statement "I enjoy creating the video" was positively supported by $97.77 \%$ of the respondents. The findings signified that $91.11 \%$ strongly agreed and $8.89 \%$ agreed that they could see their own weaknesses and strengths when using the 'Video Making' approach. Meanwhile, 88.89\% strongly agreed and $8.89 \%$ agreed this approach enable the respondents to correct themselves by rerecording. Only $1(2.22 \%)$ respondent choose neutral and the rest agreed (97.78\%) that they begin to like learning the English language. All of the respondents agreed that they were able to spend more time discussing Chapter 1 with their lecturer. As for the statement "I like recording outdoor" and "I like watching my video", 1 respondent (2.22\%) disagreed whereas the rest totally agreed to the statements respectively. Hence, it can be summarized that the implementation of the 'Video Making' approach has a huge impact on the respondents in learning the English language process

\section{ACTIONS AND INTERVENTIONS}

"Action research revolves around "teacher-initiated classroom investigation, which seeks to increase the teacher's understanding of classroom 
teaching and learning, and to bring about change in classroom practices" (Richard, J.C., (1994), p.12). Hence, the findings from this action research- video making presentation for assessments were implemented and shared with other teachers that are teaching this subject (compulsory in the assessment instruction) to improve the students' presentation in every aspect especially their confident level.

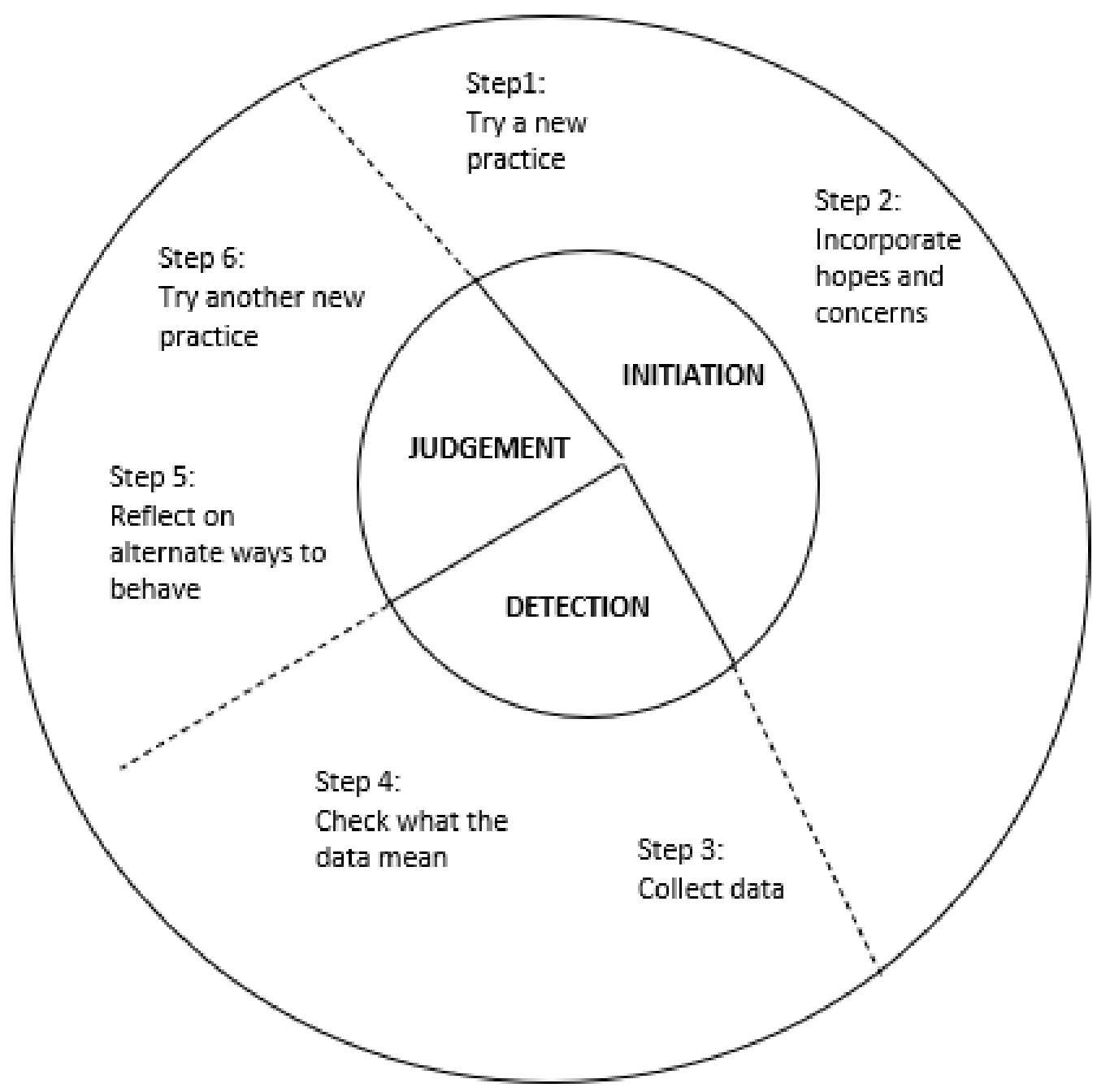

\section{CONCLUSION AND FURTHER RESEARCH}

This action research aimed to see the students' adaptation and perception towards the new assessment approach in improving the students' oral communication presentation in DUE 3012-Communicative English 2. Video provides a platform for the students to showcase their knowledge to others in an attractive way and help them to polish up their presentation skills (Martin et all., 2013). The video making approach was proven effective in developing and helping the students in their oral presentation assessment whereby they can prepare in advance and bring the actual scene into their recording rather than just presenting in front of the classroom with the background of the whiteboard. 
The students that vary from learning style and communication ability benefited from this approach and it has aided to build their confidence level in using the English language. By using the video making approach, the students can review and amend their video presentation as it provides many options when it comes to video editing. Mistakes can be minimized as the students can view their recording and rerecord their presentation to perfection. They can view themselves and identify the mistakes. Thus, it will reduce the turn-taking stress and students would be able to provide feedback to their friends on the improvement aspect.

The limitation of this study is that it only focuses on one department Information Technology. The students in this department have been exposed to the video making elements in their studies. It is recommended that future study to be conducted with students that does not study any video making elements to identify the barrier that they face in completing their video.

\section{REFERENCES}

Brown, H.D. (2000). Teaching by Principles: An Interactive Approach to language Pedagogy. New York: Addison Wesley Longman.

Greene, H. \& Crespi, C. (2012). The Value of Student Created Videos in the College Classroom - An Exploratory Study in marketing and Accounting. Retrieved from www.internationaljournal.org/ima ges/Greene.pdf

Harmer, J. (2004). The Practice of English Language Teaching, $3^{\text {rd }}$ Edition. England Longman.

Hulsizer, H. (2016). Student-produced videos for exam review in mathematics courses. International Journal

of Research in Education and Science (IJRES), 2(2), 271-278.

Ilin,G., Kutlu,Q., \& Kutluay, A. (2012). An Action Research: Using Videos for teaching grammar in an ESP

class. Retrieved from www.sciencedirect.com

Malaysia Education Blueprint 20132025. Retrieved February 13, 2014, from https://www.moe.gov.my/index.p hp/en/dasar/pelanpembangunan-pendidikanmalaysia-2013-2025

Martin, C., Coleman, G. W., \& Hughes, J. (2013). Do student-produced videos encourage critical reflection amongst undergraduate computing students? The Higher Education Academy - STEM. Retreived from https://www.heacademy.ac.uk/kn owledge-hub/do-studentproduced-videos-encouragecriticalreflection-amongst-undergraduate Ng Choo Ting (2013). Classroom Video Project: An Investigation on Students' Perception. Retrieved from www.sciencedirect.com

Richard, J.C. \& Lockhart, C. (1994). Reflective Teaching in Second Language Classrooms. Australia: Cambridge University Press

Santoso, D. (2017). Implementing Video Recording to Improve the Content of Opening Speech. Journal of English Educators Society, 2(1), 21-32. doi: http://dx.doi.org/10.21070/jees.v $\underline{2 i 1.713}$ 